\title{
EMERGENCE RATE OF THE MEXICAN BEAN WEEVIL IN VARIETIES OF BEANS FROM THE SOUTHWESTERN AMAZON ${ }^{1}$
}

\author{
LUCAS MARTINS LOPES ${ }^{2}$, JOSIANE MOURA DO NASCIMENTO², VANDERLEY BORGES DOS SANTOS ${ }^{2}$, LÊDA \\ RITA DANTONINO FARONI ${ }^{3}$, ADALBERTO HIPÓLITO DE SOUSA ${ }^{2} *$
}

\begin{abstract}
Common beans (Phaseolus vulgaris L.) are one of the most important protein sources worldwide. However, infestation by bruchids compromises the storage of these beans after harvest. The objective of this study was to determine the emergence rate of Zabrotes subfasciatus (Coleoptera: Chrysomelidae) in four P. vulgaris varieties (Carioca Pitoco, Enxofre, Gorgutuba Vermelho, and Rosinha) cultivated in the southwestern Amazon (State of Acre, Brazil). The grains from each variety were infested with 50 non-sexed adult Z. subfasciatus, and the insects were collected 13 days after initiating the bioassays. The adult progeny was collected from each plant variety on alternate days from the beginning to the end of the emergence period, and they were counted (number of insects/jar). The sum of emerged insects per day (SEd) was determined from the beginning of the emergence period, from which the accumulated emergence was calculated $(\mathrm{SEa}=\Sigma \mathrm{SEd}$, \% day). There were differences in the emergence rates of $Z$. subfasciatus among the bean varieties, with the rates being lower in the Gorgutuba Vermelho variety. Although this bean variety had the lowest peak of adult insect emergence, the period of insect development was not of increased length in this variety compared to the other varieties. In general, the Gorgutuba Vermelho variety appears to be resistant to $Z$. subfasciatus.
\end{abstract}

Keywords: Zabrotes subfasciatus. Phaseolus vulgaris. Storage. Plant resistance.

\section{AVALIAÇÃO DA TAXA DE EMERGÊNCIA DO CARUNCHO-DO-FEIJÃO EM VARIEDADES DE FEIJÃO ORIUNDAS DA AMAZÔNIA SUL-OCIDENTAL}

RESUMO - O feijão comum (Phaseolus vulgaris L.) é uma das fontes proteicas mais importantes em todo o mundo. Todavia, o ataque de bruquídeos inviabiliza o armazenamento do produto após a colheita. O objetivo deste trabalho foi determinar a taxa de emergência de Zabrotes subfasciatus (Coleoptera: Chrysomelidae) em quatro variedades de feijão P. vulgaris (Carioca Pitoco, Enxofre, Gorgutuba Vermelho e Rosinha) cultivadas na Amazônia sul-ocidental (Acre, Brasil). Os grãos de cada variedade foram infestados com 50 adultos nãosexados e após 13 dias do início dos bioensaios, os insetos foram removidos. A progênie adulta obtida nas variedades foi contabilizada e removida em dias alternados, a partir da primeira emergência, até o final do período de emergência ( $\mathrm{n}^{\circ}$ de insetos/frasco). A soma da emergência de insetos foi acumulada a partir da emergência inicial e resultou na soma da emergência acumulada ( $\mathrm{SEa}$ \% \% dia), calculada por SEa $=\sum \mathrm{SEd}$. Foram constadas diferenças nas taxas de emergência de $Z$. subfasciatus entre as variedades de feijão, sendo que a variedade Gorgutuba Vermelho apresentou menor taxa de emergência. Embora esta variedade de feijão tenha apresentado menor emergência de adultos, o tempo de desenvolvimento dos insetos não se estendeu nesta variedade, em comparação com as outras variedades. Em geral, a variedade Gorgutuba Vermelho apresentou indícios de fontes resistência a Z. subfasciatus.

Palavras-chave: Zabrotes subfasciatus. Phaseolus vulgaris. Armazenamento. Resistência de plantas.

\footnotetext{
${ }^{*}$ Corresponding author

${ }^{1}$ Received for publication in 02/14/2017; accepted in 03/08/2018

Paper extracted from the master thesis of the first author.

${ }^{2}$ Center for Biological and Nature Sciences, Universidade Federal do Acre, Rio Branco, AC, Brazil; lucas.lopes@ufac.br - ORCID: 00000001-7686-4997, josianemouran@hotmail.com - ORCID: 0000-0001-7979-0137, vanderley@ufac.br - ORCID: 0000-0002-1090-9280, adalberto@ufac.br - ORCID: 0000-0002-3089-2762.

${ }^{3}$ Department of Agricultural Engineering, Universidade Federal de Viçosa, Viçosa, MG, Brazil; leda@ufv.br - ORCID: 0000-0001-86485034 .
} 


\section{INTRODUCTION}

Common beans, Phaseolus vulgaris L. (Fabaceae), are one of the most widely used vegetables in the world due to their economic and nutritional importance. These beans are a source of essential nutrients for human consumption and provides income to small farmers in developing countries (MUTANGI et al., 2015; JONES; ALEXANDER; LOWENBERG-DEBOER, 2017). In the Amazon region, native bean varieties are grown and stored on the farm until the following crop cycle (LOPES et al., 2016). Landrace varieties are considered an important genetic source for pest resistance because these varieties have a broader genetic base and a greater proportion of distinct genes directly related to their large genetic diversity (ASFAW; BLAIR; ALMEKINDERS, 2009; TIGIST et al., 2018).

In Brazil, the bruchid Zabrotes subfasciatus (Coleoptera: Chrysomelidae) stands out as one of the main insect pests of the common bean (FARONI; SOUSA, 2006; COSTA et al., 2014; JAIROCE et al., 2016). The control of insect pests in stored products is traditionally achieved with pyrethroids, organophosphates, and the fumigant phosphine $\left(\mathrm{PH}_{3}\right)$ (CORRÊA et al., 2011; SOUSA; FARONI; FREITAS, 2014). However, the continuous and indiscriminate application of these products for pest control has been questioned worldwide, both for causing mortality in non-target organisms and for the residual insecticide levels remaining in the food and the consequent health risks to the consumers (COSTA et al., 2014; FREITAS; FARONI; SOUSA, 2016).

As an alternative to synthetic insecticides, the use of plant varieties resistant to bruchids has been recommended. The genetic resistance of plants has been widely studied and noted as one of the most efficient forms of pest and disease control, since it is compatible with any other method and does not cause health and environmental risks (APPLEBY; CREDLAND, 2004; KUSOLWA; MYERS, 2011).

Reserve proteins present in beans may limit the attack of bruchids, due to their toxic properties, which give the plants antibiosis resistance (EDUARDO et al., 2016). The reserve protein arcelin is homologous to lectin and has been identified in varieties of landrace beans resistant to $Z$. subfasciatus. This protein has been successfully reproduced in cultivated bean lines (CARDONA et al., 1990).

In view of the above and considering that Latin America is acknowledged as one of the genetic diversity centers of $P$. vulgaris (VELTEN et al., 2007; OLIVEIRA et al., 2013), the objective of this study was to determine the rate of emergence of $Z$. subfasciatus in four landrace varieties of $P$. vulgaris occurring in the Southwestern Amazon region and extensively grown in the Brazilian state of Acre.

\section{MATERIAL AND METHODS}

The bioassays were conducted at the Entomology Laboratory, Federal University of Acre, Rio Branco campus. The municipality of Rio Branco, Acre is located at latitude $9^{\circ} 58^{\prime} 29^{\prime \prime}(\mathrm{S})$ and longitude $67^{\circ} 48^{\prime} 36^{\prime \prime}(\mathrm{W}), 153 \mathrm{~m}$ above sea level.

The stock colony was established from $Z$. subfasciatus specimens collected in a rural property located in the same municipality. The stock was maintained under constant temperature conditions of $\left(27 \pm 2{ }^{\circ} \mathrm{C}\right)$, relative humidity $(70 \pm 5 \%)$, and scotophase $(24 \mathrm{~h})$. The insects were reared in 1.5-L glass bottles containing beans of the Pérola variety with $13 \%$ moisture content, and the bottles had been previously cooled to $-18{ }^{\circ} \mathrm{C}$ to avoid pre-infestation. The tenth generation offspring was used in the bioassays.

The rates of daily emergence and cumulative emergence of $Z$. subfasciatus were determined in the following bean varieties: Carioca Pitoco, Enxofre, Gorgutuba Vermelho, and Rosinha. These varieties are among the most commonly cultivated varieties in the Acre communities and are well-distributed in the Southwestern Amazon. The bioassays were conducted under the same environmental conditions referred to above for the multiplication of the stock colony.

The emergence bioassays were adapted from Trematerra, Fontona and Mancini (1996), and from Sousa et al. (2009). Plastic 350-mL jars with $150 \mathrm{~g}$ of beans from each variety were used. The beans were infested with 50 non-sexed adults, aged up to 48 hours. The insects were removed from the jars 13 days after the beginning of the bioassays, and the beans were stored until the emergence of the insect progeny. The adult progeny obtained was counted and removed every other day $(1,3,5,7,9,11,13$, $15,17,19,21,23$ days) from the first emergent insect to the end of the emergence period.

The normalized cumulative emergence rate was analyzed first. The sum of the emergence of insects was accumulated from the initial emergence, resulting in the cumulative emergence (SEa, \% day), calculated as $\mathrm{SEa}=$ ÓSEd. The cumulative emergence data were analyzed because experimental errors are more likely if only the evaluation data of the emergence of insects on alternate days are considered due to the influence of the sampling times (TREMATERRA; FONTONA; MANCINI, 1996; SOUSA et al., 2009; LOPES et al., 2016).

The experimental design was completely randomized with four treatments (one for each variety) and four replications. The emergence data on alternate days and the cumulative emergence data were subjected to nonlinear modeling using SigmaPlot software. 


\section{RESULTS AND DISCUSSION}

The three-parameter sigmoid model $(y=a / 1+\exp (-(x-b) / c))$ was the best fit for the cumulative emergence of $Z$. subfasciatus adults $\left(\mathrm{P}<0.0001 ; \mathrm{R}^{2}=0.99\right.$; Table 1 and Figure 1$)$. The cumulative emergence curves varied among varieties with an inflection point (maximum emergence rate) between 7 and 11 days (Table 1). The curve of the Carioca Pitoco variety presented the highest inflection point (11.72 \pm 0.05 days), suggesting a later emergence, followed by Enxofre $(9.57 \pm 0.13$ days), Gorgutuba Vermelho $(8.79 \pm 0.13$ days $)$, and Rosinha (7.82 \pm 0.09 days $)$ (Table 1).

Table 1. Summary of the non-linear regression analyzes of the Z. subfasciatus emergence.

\begin{tabular}{|c|c|c|c|c|c|c|c|}
\hline \multirow{2}{*}{ Variable } & \multirow{2}{*}{ Model } & \multirow{2}{*}{ Variety } & \multicolumn{3}{|c|}{ Estimated parameters $( \pm \mathrm{SE})$} & \multirow[t]{2}{*}{$\mathrm{F}$} & \multirow[t]{2}{*}{$\mathrm{R}^{2}$} \\
\hline & & & $\mathrm{a}$ & $\mathrm{b}$ & c & & \\
\hline \multirow{4}{*}{$\begin{array}{l}\text { Normalized } \\
\text { Cumulative } \\
\text { Emergence }\end{array}$} & \multirow{4}{*}{$\begin{array}{l}y=a / 1+ \\
\exp (-(x-b) / c)\end{array}$} & Carioca Pitoco & $99.52 \pm 0.70$ & $11.72 \pm 0.05$ & $0.89 \pm 0.04$ & 05673.33 & 0.99 \\
\hline & & Enxofre & $98.47 \pm 1.43$ & $9.57 \pm 0.13$ & $1.03 \pm 0.11$ & 41086.05 & 0.99 \\
\hline & & $\begin{array}{l}\text { Gorgutuba } \\
\text { Vermelho }\end{array}$ & $99.54 \pm 1.25$ & $8.79 \pm 0.13$ & $1.40 \pm 0.11$ & 11356.66 & 0.99 \\
\hline & & Rosinha & $99.17 \pm 0.91$ & $7.82 \pm 0.09$ & $1.01 \pm 0.07$ & 02093.62 & 0.99 \\
\hline \multirow{4}{*}{ Emergence } & \multirow{4}{*}{$\begin{array}{l}y=a \exp (- \\
\left.0.5((x-b) / c)^{2}\right)\end{array}$} & Carioca Pitoco & $339.77 \pm 11.09$ & $12.78 \pm 0.06$ & $1.38 \pm 0.05$ & 00461.73 & 0.99 \\
\hline & & Enxofre & $275.34 \pm 24.29$ & $10.18 \pm 0.16$ & $1.67 \pm 0.18$ & 01074.70 & 0.93 \\
\hline & & Gorgutuba & $144.37 \pm 13.85$ & $9.66 \pm 0.29$ & $2.62 \pm 0.29$ & 01052.52 & 0.90 \\
\hline & & Rosinha & $293.49 \pm 11.61$ & $11.93 \pm 0.09$ & $2.01 \pm 0.09$ & 00327.65 & 0.98 \\
\hline
\end{tabular}

Where normalized cumulative emergence $(\mathrm{a}=$ maximum value, $\mathrm{b}=$ inflection point, and $\mathrm{c}=$ curve shape); emergence ( $\mathrm{a}=$ emergence peak, $\mathrm{b}=$ time in days when the emergence peak occurs, and $\mathrm{c}=$ standard deviation of parameter $\mathrm{b}$ ); standard error of the mean (SE). All estimated parameters were significant at $\mathrm{P}<0.01$ by Student's $t$-test and all the models were significant at $\mathrm{P}<0.01$ by Fisher's F-test.

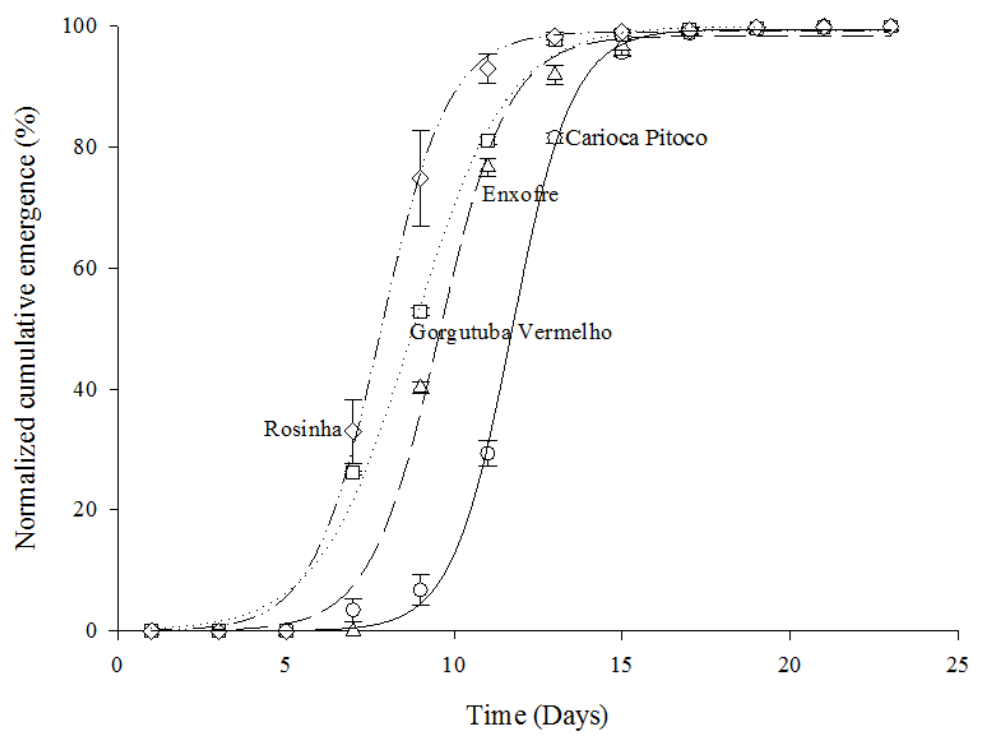

Figure 1. Normalized cumulative emergence of $Z$. subfasciatus in four landrace varieties of $P$. vulgaris (Carioca Pitoco (०), Enxofre $(\Delta)$, Gorgutuba Vermelho $(\square)$, and Rosinha $(\diamond))$. The symbols represent the means of the repetitions. The parameters of the equations are presented in Table 1.

The Gaussian model with three parameters $\left(y=a \exp \left(-0.5((x-b) / c)^{2}\right)\right.$ was the best fit for the emergence of $Z$. subfasciatus adults $(\mathrm{P}<0.0001$; $\mathrm{R}^{2} \geq 0.90$; Table 1 and Figure 2). There were obvious emergence rate differences among varieties; the lowest value was observed in Gorgutuba Vermelho, which reached the maximum emergence in 9 days (Figure 2 and Table 1).

The results indicate considerable variation in the emergence of $Z$. subfasciatus among the varieties of landrace beans tested. The Gorgutuba Vermelho revealed less susceptibility to bruchids. Changes in patterns of susceptibility to bruchids have been reported for different bean varieties from South America and the rest of the world (BALDIN; PEREIRA, 2010; EDUARDO et al., 2016).

Although the lowest emergence rate of $Z$. subfasciatus was recorded in Gorgutuba Vermelho, 
the normalized cumulative emergence was longer in Carioca Pitoco. This observation does not allow a relationship between the development period and the emergence rate in the varieties studied to be established. Similar results were obtained by Lopes et al. (2016), who did not find an association between the emergence rate and the development period in landrace varieties of beans attacked by $Z$. subfasciatus. However, other authors have observed that bruchid resistance is associated with prolonged population development, reduced insect emergence, and reduced mass loss (COSTA et al., 2013; BOIÇA JÚNIOR et al., 2015; EDUARDO et al., 2016).

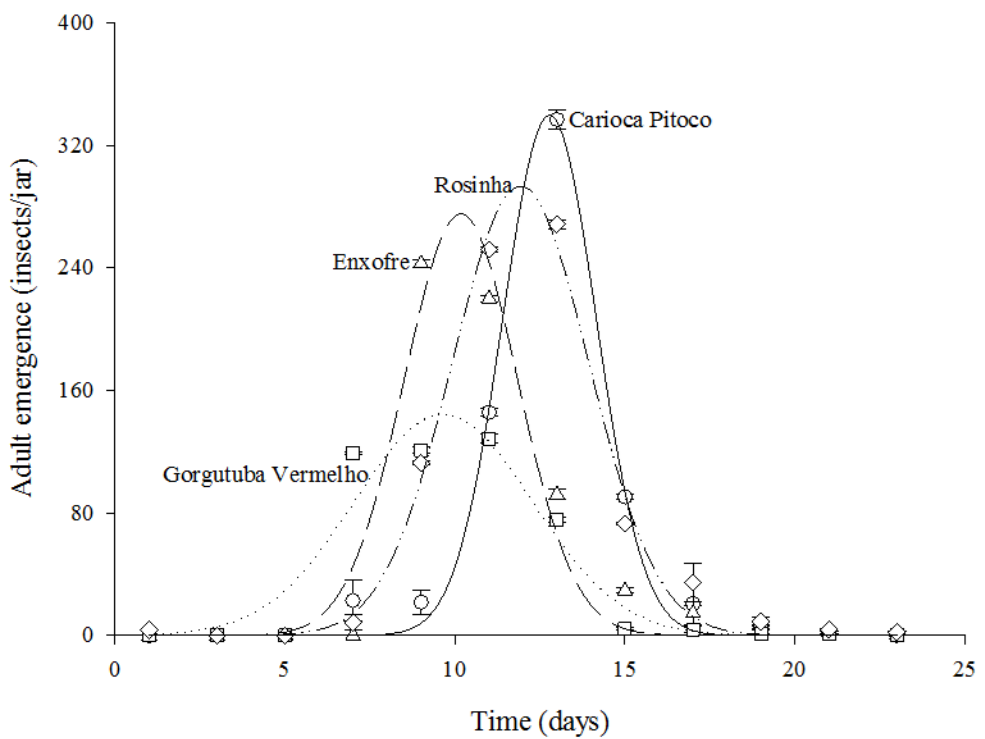

Figure 2. Emergence of Z. subfasciatus adults in four landrace varieties of P. vulgaris (Carioca Pitoco $(\circ)$, Enxofre $(\Delta)$, Gorgutuba Vermelho $(\square)$, and Rosinha $(\diamond))$. The symbols represent the means of the repetitions. The parameters of the equations are presented in Table 1.

The genetic variability of $P$. vulgaris has been related to distinct diversity centers, known as the Mesoamerican gene pool and the Andean gene pool (OLIVEIRA et al., 2013). For decades, in these regions, farmers have cultivated complex mixtures of bean types as hedges against pests and diseases. This process produced a great genetic variability of color, texture, chemical composition, seed size, and resistance levels against bruchids (BONFIM et al., 2007). Hence, it is understandable that there are differences in both the normalized cumulative emergence rate and the adult emergence rate among the bean varieties studied (LOPES et al., 2016).

Antibiosis resistance in bean genotypes can be expressed in several ways; among these, defense proteins stand out (EDUARDO et al., 2016). The analysis of the chemical nature of these proteins may contribute to the elucidation of the causes of lower emergence of $Z$. subfasciatus in Gorgotuba Vermelho. Arcelin is a well-known protein with insecticidal properties that affect the larval development of bruchids, consequently reducing the number of emerged insects and their mass consumption (JANARTHANAN et al., 2008). Plant proteins with insecticidal properties have great potential in agricultural biotechnology, given that they are directly related to the development of a plant's resistant to pest attacks.

The prolonged development of bruchids in
Enxofre and Carioca Pitoco, where a higher emergence of $Z$. subfasciatus was observed, may have unfavorable consequences for the insects under storage conditions. It is worth mentioning that with the extension of the larval stage, the insects become more susceptible to attack from natural enemies and to climatic extremes. This extended development also favors competition for essential resources to ensure their survival (GUEDES; GUEDES; SMITH, 2007; CRUZ et al., 2016).

The study of the susceptibility of varieties of landrace beans is of fundamental importance to integrated pest management and breeding programs targeted at resistance sources. In general, the emergence rate of $Z$. subfasciatus was lower in Gorgutuba Vermelho, which may be an indication of bruchid resistance. The recommendation to grow bean varieties less susceptible to the attack of $Z$. subfasciatus could allow the extension of the product's storage period, thereby enabling commercialization to take place when the net income is higher (LOPES et al., 2016).

\section{CONCLUSIONS}

Variations in the emergence of $Z$. subfasciatus indicate different patterns of insect susceptibility in the beans tested. The lowest daily 
emergence rate was recorded in the Gorgutuba Vermelho variety, but the normalized cumulative emergence was observed over a longer time period in the Carioca Pitoco variety. A relationship could not be established between the development period and the emergence rate in the varieties studied.

\section{ACKNOWLEDGMENTS}

The authors are grateful for the funding and scholarships offered by the following institutions: Coordenação de Aperfeiçoamento de Pessoal de Nível Superior (CAPES), Conselho Nacional de Desenvolvimento Científico e Tecnológico (CNPq) and the Fundação de Amparo à Pesquisa do Estado do Acre (FAPAC).

\section{REFERENCES}

APPLEBY, J. H.; CREDLAND, P. F. Environmental conditions affect the response of West African Callosobruchus maculatus (Coleoptera: Bruchidae) populations to and resistant cowpeas. Journal of Stored Products Research, Amsterdam, v. 40, n. 3, p. 269-287, 2004.

ASFAW, A.; BLAIR, M. W.; ALMEKINDERS, C. Genetic diversity and population structure of common bean (Phaseolus vulgaris L.) landraces from the East African highlands. Theoretical and Applied Genetics, Stuttgart, v. 120, n. 1, p. 1-12, 2009.

BALDIN, E. L. L.; PEREIRA, J. M. Resistencia de genótipos de feijoeiro a Zabrotes subfasciatus (Boheman, 1833) (Coleoptera: Bruchidae). Ciência e Agrotecnologia, Lavras, v. 34, n. 6, p. 1507-1513, 2010.

BOIÇA JÚNIOR, A. L. et al. A defesa das plantas ao ataque dos insetos. In: BUSOLI, A. C. et al. (Eds.). Tópicos em entomologia agrícola - VIII. Jaboticabal: Multipress, 2015. v. 1, cap. 15, p. $207-$ 224.

BONFIM, K. A. C. et al. RNAi-mediated resistance to Bean golden mosaic virus in genetically engineered common bean (Phaseolus vulgaris). Molecular Plant-Microbe Interactions, St. Paul, v. 20, n. 6, p. 717-726, 2007.

CARDONA, C. et al. Comparative value of 4 arcelin variants in the development of dry bean lines resistant to the Mexican Bean Weevil. Entomologia Experimentalis et Applicata, Dordrecht, v. 56, n. 2, p. 197-206, 1990.
CORRÊA, A. S. et al. Insecticide resistance, mixture potentiation and fitness in populations of the maize weevil (Sitophilus zeamais). Crop Protection, Oxford, v. 30, n. 12, p. 1655-1666, 2011.

COSTA, E. N. et al. Divergência genética de genótipos de feijoeiro a infestação de Zabrotes subfasciatus (Bohemann) (Coleoptera: Bruchidae). Semina, Londrina, v. 34, n. 6 p. 2737-2752, 2013.

COSTA, J. T. et al. Effects of different formulations of neem oil-based products on control Zabrotes subfasciatus (Boheman, 1833) (Coleoptera: Bruchidae) on beans. Journal of Stored Products Research, Amsterdam, v. 56, n. 1, p. 49-53, 2014.

CRUZ, L. P. et al. Evaluation of resistance in different cowpea cultivars to Callosobruchus maculatus infestation. Journal of Pest Science, Berlin, v. 89, n. 1, p. 117-128, 2016.

EDUARDO, W. I. et al. Antibiosis levels of common bean genotypes toward Zabrotes subfasciatus (Boheman) (Coleoptera: Bruchidae) and its correlation with flavonoids. Journal of Stored Products Research, Amsterdam, v. 67, n. 3, p. 63 70, 2016.

FARONI, L. R. D. A.; SOUSA, A. H. Aspectos biológicos e taxonômicos dos principais insetospraga de produtos armazenados. In: ALMEIDA, F. A. C.; DUARTE, M. E. M.; MATA, E. R. M. C. (Eds.). Tecnologia de armazenagem em sementes. Campina Grande: UFCG, 2006. v. 1, cap. 7, p. $371-$ 402.

FREITAS, R. S.; FARONI, L. R. A.; SOUSA, A. H. Hermetic storage for control of common bean weevil, Acanthoscelides obtectus (Say). Journal of Stored Products Research, Amsterdam, v. 66, n. 2, p. 1-5, 2016.

GUEDES, R. N. C.; GUEDES, N. M. P.; SMITH, R. $\mathrm{H}$. Larval competition within seeds: from the behavior process to the ecological outcome in the seed beetle Callosobruchus maculatus. Austral Ecology, Carlton, v. 32, n. 6, p. 697-707, 2007.

JAIROCE, C. F. et al. Insecticide activity of clove essential oil on bean weevil and maize weevil. Revista Brasileira de Engenharia Agrícola e Ambiental, Campina Grande, v. 20, n. 1, p. 72-77, 2016

JANARTHANAN, S. et al. Arcelin from Indian wild pulse, L. purpureus and insecticidal activity in storage pests. Journal of Agricultural and Food Chemistry, Washington, v. 56, n. 5, p. 1676-1682, 2008. 
JONES, M.; ALEXANDER, C.; LOWENBERGDEBOER, J. Profitability of hermetic purdue improved crop storage (pics) bags for African common bean producers. Disponível em: $<\mathrm{http}: / /$ ageconsearch.umn.edu/bitstream/117708/2/116.pdf>. Acesso em: 08 jan. 2017.

KUSOLWA, P. M.; MYERS, J. R. Seed storage proteins Arl2 and its variants from the apa locus of wild tepary bean G40199 confers resistance to Acanthoscellides obtectus when expressed in common beans. African Crop Science Journal, Kampala, v. 19, n. 4, p. 255-265, 2011.

LOPES, L. M. et al. Population development of Zabrotes subfasciatus (Coleoptera: Chrysomelidae) in landrace bean varieties occurring in southwestern Amazonia. Journal of Economic Entomology, Oxford, v. 109, n. 1, p. 467-471, 2016.

MUTANGI, C. et al. Trip-layer plastic bags protect dry common beans (Phaseolus vulgaris) against damage by Acanthoscelides obtectus (Coleoptera: Chrysomelidae) during storage. Journal of Economic Entomology, Oxford, v. 108, n. 5, p. 2479-2488, 2015.

OLIVEIRA, M. R. C. et al. Mesoamerican origin and pre- and post-columbian expansions of the ranges of Acanthoscelides obtectus say, a cosmopolitan insect pest of the common bean. Plos One, California, v. 8, n. 7, p. 1-12, 2013.

SOUSA, A. H.; FARONI, L. R. D.; FREITAS, R. S. Relative toxicity of mustard essential oil to insectpests of stored products. Revista Caatinga, Mossoró, v. 27, n. 2, p. 222-226, 2014.

SOUSA, A. H. et al. Developmental and population growth rates of phosphine-resistant and - susceptible populations of stored product insect-pests. Journal of Stored Products Research, Amsterdam, v. 45, n. 4, p. 241-246, 2009.

TIGIST, S. G. et al. Evaluation of different Ethiopian common bean, Phaseolus vulgaris (Fabaceae) genotypes for host resistance to the Mexican bean weevil, Zabrotes subfasciatus (Coleoptera: Bruchidae). International Journal of Tropical Insect Science, New York, v. 38, n. 1, p. 1-15, 2018.

TREMATERRA, P.; FONTONA, F.; MANCINI, M. Analysis of development rates of Sitophilus oryzae (L.) in five cereals of the genus Triticum. Journal of Stored Products Research, Amsterdan, v. 32, n. 4, p. $315-322,1996$.
VELTEN, G. et al. The inhibitory effect of the natural seed storage protein arcelin on the development of Acanthoscelides obtectus. Journal of Stored Products Research, Amsterdam, v. 43, n. 3, p. 550-557, 2007. 